\title{
Footrace to clinic heats up for T-cell nuclear receptor inhibitors
}

Ann Arbor, Michigan-based Lycera and covery deal over undisclosed targets in autoimmune disease, earning the biotech an upfront payment and potentially over $\$ 300$ million in milestones. The companies report that their first partnership to develop inhibitors of retinoic acid-related orphan receptor gamma $t$ (ROR $\gamma \mathrm{t}$ ) remains on track. Since the two firms began to collaborate (Nat. Biotechnol. 29, 679, 2011), several other big pharma and biotech firms (Table 1) have joined forces in the race to validate inhibitors of this nuclear receptor that plays a key role in the differentiation of naive $\mathrm{CD} 4^{+} \mathrm{T}$ cells into T-helper 17 $\left(\mathrm{T}_{\mathrm{H}} 17\right)$ cells. population characterized by the production in host defenses against microbial pathogens, but chronically excessive levels of these cells have been implicated in a wide range of autoimmune conditions. Interest in $\mathrm{T}_{\mathrm{H}} 17$ cell biology has been spurred by the spectacular clinical results obtained in treating psoriasis with antibodies that target either IL-17 or the p19 subunit of IL-23, a cytokine involved with maintenance of the $\mathrm{T}_{\mathrm{H}} 17$ phenotype (Nat. Biotechnol. 30, 475-477, 2012). However, $\mathrm{T}_{\mathrm{H}} 17$ cells may not be the only players in psoriasis, says Gary Glick, who is at the University of Michigan, Ann Arbor, noting that $\gamma \delta$ T-cells also produce IL-17 and have also been implicated in the disease pathology. The picture in other autoimmune indications is cloudier, although also less mature-psoriasis, as a topical indication, lends itself well to early drug development.

ROR $\gamma t$ inhibitors have yet to enter human trials in any indication. "There's a lot of chest beating about who will be first into the clinic," says Don Nicholson, vice president and head of worldwide discovery, respiratory and immunology, at Merck of Whitehouse Station, New Jersey. "Our strategy is, try to get a molecule as Merck entered a second small-molecule dis-

$\mathrm{T}_{\mathrm{H}} 17$ cells are a pro-inflammatory cell of interleukin 17 (IL-17). They are involved
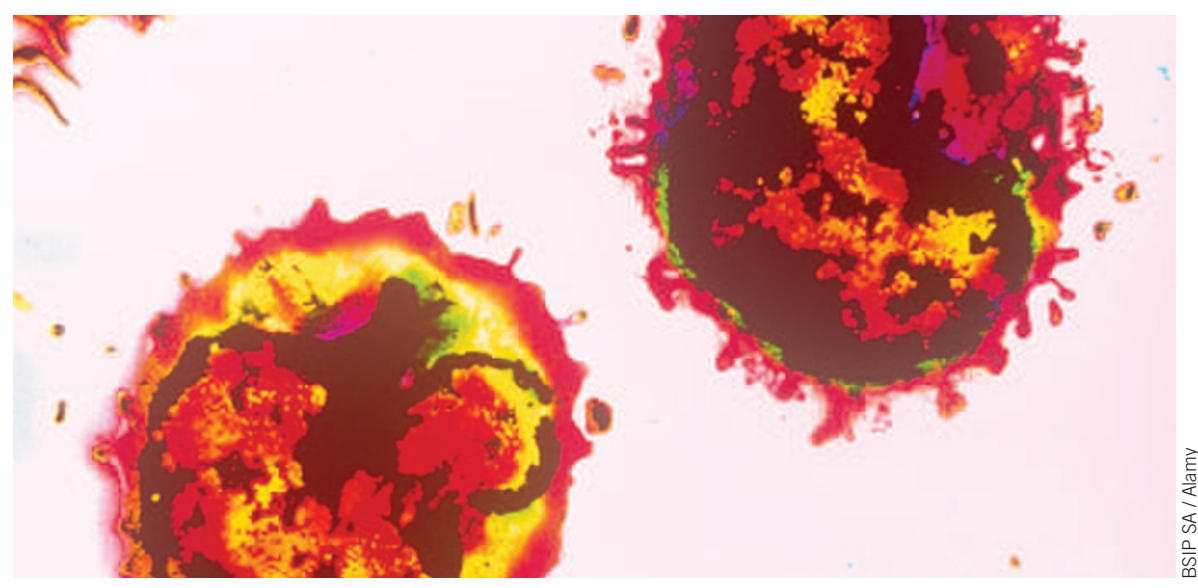

Companies are racing to develop inhibitors of T cell nuclear receptors to manipulate T-helper 17 biology. quickly as we can, but a molecule that is likely to make it all the way as a drug." The target has attracted big pharma interest as it offers a more global way of modulating $\mathrm{T}_{\mathrm{H}} 17$ biology than hitting targets such as IL-17 or IL-23, whereas its tissue selectivity-it is expressed mainly in the thymus and at certain mucosal surfaces-should ensure potential toxicities are limited, drug developers hope. In the absence of clinical data, it remains an open question for now whether it represents the best entry point for manipulating $\mathrm{T}_{\mathrm{H}} 17$ biology. "I think it's a compelling target. As we begin to dissect out $\mathrm{T}_{\mathrm{H}} 17$ cell biology, it could turn out to be the best target; it could be a good target among others; or it could be an inferior target," says Nicholson.

The complexity of $\mathrm{T}_{\mathrm{H}} 17$ biology has recently been underlined in a transcriptional profiling, time-course study from Vijay Kuchroo, of Harvard Medical School, and collaborators, who recently identified 71 regulatory factors (46 of them new) in an extensive regulatory network controlling $\mathrm{T}_{\mathrm{H}} 17$ cell differentiation (Nature doi:10.1038/ nature11868, 6 March 2013). Kuchroo is also a co-founder of Tempero Pharmaceuticals, of

\begin{tabular}{|c|c|c|c|}
\hline Company & Partner & Potential value & Date \\
\hline $\begin{array}{l}\text { Orphagen Pharmaceuticals } \\
\text { (San Diego) }\end{array}$ & Japan Tobacco (Tokyo) & Not disclosed & 1/07/09 \\
\hline $\begin{array}{l}\text { Exelixis (S. San Francisco, } \\
\text { California) }\end{array}$ & Bristol-Myers Squibb (New York) & $\$ 285$ million & $10 / 11 / 10$ \\
\hline Lycera & Merck & $\$ 300$ million & $3 / 03 / 11$ \\
\hline Karo Bio (Huddinge, Sweden) & Pfizer (New York) & $\$ 217$ million & $12 / 24 / 11$ \\
\hline $\begin{array}{l}\text { Phenex Pharmaceuticals } \\
\text { (Ludwigshafen, Germany) }\end{array}$ & $\begin{array}{l}\text { Johnson \& Johnson (New } \\
\text { Brunswick, New Jersey) }\end{array}$ & $\$ 135$ million $^{a}$ & $12 / 17 / 12$ \\
\hline
\end{tabular}

Cambridge, Massachusetts, a company formed in 2009 with backing from London-based GlaxoSmithKline, which is focused on suppressing $\mathrm{T}_{\mathrm{H}} 17$ cells and enhancing regulatory T cells ( $\mathrm{T}_{\text {reg }}$ cells) to treat autoimmune disease. At the International Conference on Clinical \& Cellular Immunology on October 22-24, 2012, in Chicago, the company presented results on several small-molecule inverse agonists of ROR $\gamma \mathrm{t}$ (J. Clin. Cell Immunol. 3, 4, 2012), but it is working on several other undisclosed targets. Kuchroo's study has identified "another boatload of potential targets," says Mark Sundrud, of the Scripps Research Institute in Jupiter, Florida, who previously worked at Tempero. But it will take time for the field to sift through these putative targets and link them to actual functions, he says. Sundrud was first author on an earlier study which showed that activation of the amino acid starvation response selectively inhibited $\mathrm{T}_{\mathrm{H}} 17$ differentiation while boosting $\mathrm{T}_{\text {reg }}$ cell activation (Science 324, 1334-1338, 2009). Why this effect is limited to $T_{H} 17$ cells is unclear. "One of the thoughts is amino acid deprivation is playing a part in the resolution of inflammation," Sundrud says. Limited local availability of amino acids could act as a brake on the inflammatory response. "This has nothing to do with dietary restriction," he observes. In contrast, a study published back to back with the Kuchroo study suggests that dietary salt is a driver of autoimmune disease through $\mathrm{T}_{\mathrm{H}} 17$ cell activation. Glick plays down its significance, however. "I'd be very cautious about drawing conclusions about cause and effect. Correlations and causality are very different," he says. Corrected after print 27 June 2013. 


\section{Erratum: Footrace to clinic heats up for T-cell nuclear receptor inhibitors}

Cormac Sheridan

Nat. Biotechnol. 31, 370 (2012); published online 8 May 2013; corrected after print 27 June 2013.

In the version of this article initially published, Gary Glick's affiliation was given incorrectly. He is at the University of Michigan, Ann Arbor, not at the University of Wisconsin, Madison. The error has been corrected in the PDF and HTML versions of this article. 